\title{
The action of subconjunctival cyclophosphamide in rabbits
}

\author{
Ação da ciclofosfamida subconjuntival em coelhos
}

Juliana Almodin ${ }^{1}$ http://orcid.org/0000-0001-6798-1307

Flavia Almodin² http://orcid.org/0000-0001-6497-8591

Edna Almodin ${ }^{3}$ http://orcid.org/0000-0002-7609-4432

Marcio Mendes ${ }^{4}$ http://orcid.org/0000-0001- 9973-0297

Tadeu Cvintal ${ }^{5}$ http://orcid.org/0000-00001-5324-5253

Remo Susanna Junior ${ }^{6}$ http://orcid.org/0000-0001-9147-9528

\begin{abstract}
Objective: To observe clinically, in rabbits, the side effects of topical injection of subconjunctival cyclophosphamide, studying its role as an antifibrotic drug. Methods: Prospective study in 20 albino rabbits of New Zealand race. All rabbits were treated with cyclophosphamide, $10 \mathrm{mg} / \mathrm{ml}$ in a volume of $0.3 \mathrm{ml}$, in the left eye through subconjunctival injection. They were evaluated for 1, 7, 30, and 60 days after the procedure. All the animals were examined for the detection of ocular reactions such as necrosis, hyperemia, chemosis, secretion, opacity, and iritis. Other side effects as changes in the behavior, in the feed, and the water consumption were also evaluated. Results: It was observed that from the 20 rabbits studied, three rabbits (15\%) showed side effects only at the 24 hours analysis. One rabbit (5\%) presented hyperemia, one rabbit (5\%) had hyperemia associated with iritis, and one rabbit (5\%) presented hyperemia associated with secretion. These reactions were not observed at 1, 7, 30, and 60 days. Conclusion: Cyclophosphamide subconjunctival injection induces minor side effects on the conjunctiva of rabbits such as hyperemia, associated with iritis and secretion.
\end{abstract}

Keywords: Mitomycin; Cyclophosphamide; Fibroblasts; Necrosis, healing; Antifibrotic drugs; Rabbits

\section{ReSUMO}

Objetivo: Observar clinicamente os efeitos colaterais de injeção subconjuntival de ciclofosfamida, pensando em sua ação como um agente antifibrótico. Métodos: Estudo prospectivo realizado com 20 coelhos albinos da raça Nova Zelândia. Todos os coelhos foram submetidos a $0,3 \mathrm{ml}$ de injeção subconjuntival de ciclofosfamida $10 \mathrm{mg} / \mathrm{ml}$ no olho esquerdo e foram avaliados de acordo com os efeitos locais no primeiro dia após a injeção, 7, 30 e 60 dias. Foram examinados para detecção de reações oculares como necrose, hiperemia, quemose, secreção, opacidade corneana, irite além de alterações comportamentais e variação no consumo de água e alimentação. Resultados: Dos 20 coelhos estudados, apenas 3 apresentaram reações oculares e somente na leitura de 24 horas. Um coelho (5\%) apresentou hiperemia, 1 coelho (5\%) apresentou hiperemia associada a presença de irite e 1 coelho (5\%) apresentou hiperemia associada a presença de secreção. As reações não foram mais observadas durante os exames de 7,30 e 60 dias. Conclusão: A ciclofosfamida subconjuntival causou poucos efeitos colaterais na conjuntiva dos coelhos. Os únicos efeitos encontrados foram hiperemia, irite e secreção.

Descritores: Mitomicina; Ciclofosfamida; Fibroblastos; Necrose; Cicatrização; Drogas antifibróticas; Coelhos

\footnotetext{
'Posgraduated Program, Universidade de São Paulo, São Paulo, SP, Brazil.

2Provisão Hospital de Olhos de Maringa, PR, Brazil.

${ }^{3}$ Provisão Hospital de Olhos de Maringa, PR, Brazil.

${ }^{4}$ Universidade de São Paulo, São Paulo, SP, Brazil.

${ }^{5}$ Instituto de Oftalmologia Tadeu Cvintal, Sao Paulo, SP, Brazil.

${ }^{6}$ Department of Ophthalmology, Universidade de São Paulo, São Paulo, SP, Brazil.
}

The authors declare no conflict of interest

Received for publication 16/6/2020 - Accepted for publication 11/11/2020 


\section{INTRODUCTION}

$\mathbf{T}$ The first attempts to decrease the intraocular pressure (IOP) in glaucoma, with surgery, date from the first half of the nineteenth century. However, it was only in the 60 s, with the introduction of trabeculectomy by Sugar and Cairns, that the filtering surgery for glaucoma has widespread acceptance. ${ }^{(1)}$

Trabeculectomy is the most common surgery used to treat the majority cases of glaucoma. ${ }^{(2)}$ The objective of this filtering surgery is to reduce and maintain IOP at a level that will prevent further damage to the optic nerve $(\mathrm{ON})$ and visual field $(\mathrm{VF}) \mathrm{.}^{(3)}$ It is a surgery in which you want to obtain an suitable inhibition of wound healing to succeed in the intervention. The greatest success of this surgery is obtained with the formation and maintenance of a filtering bleb, which regulates the flow of aqueous humor, and therefore, it is essential to modulate the healing processes. The main cause of late failure is the formation of fibrosis in the endothelial and episcleral tissue. This fibrosis blocks the passage of aqueous humor due to the proliferation of the healing tissue composed by fibroblasts, new vessels, collagen, and other extracellular components specific to the physiological healing process that clog the filtration of the anterior chamber of the subconjunctival space. ${ }^{(4)}$ Late failure can occur weeks, months and years after surgery. Some patients have a higher risk for surgical failure, as those with eyes with inflammatory glaucoma, neovascular glaucoma, aphakic and pseudophakic eyes and eyes that underwent prior surgery. ${ }^{(3)}$

Histological studies in humans and animals suggest that failure of the surgery is associated with the presence of dense fibrovascular tissue at the surgical site. The healing process that causes the accumulation of this fibrovascular tissue is a result of migration and cell proliferation associated with the formation of new vessels with deposits of extracellular material. ${ }^{(4)}$

Numerous authors, analyzing the various factors that affect the healing process of filtering surgery, propose the use of different drugs and specific methods in order to improve their results. ${ }^{(2)}$ The current lines of research addresses the use of fibroblast inhibitors and antimetabolites such as 5-Fluoracil (5-FU) and mitomycin C (MMC)..$^{(4)}$

5-FU is a drug able to inhibit the proliferation of fibroblasts in vitro and in vivo, reducing collagen synthesis and scar formation. The drug can be injected into the subconjunctival space in the postoperative period, or applied under the conjunctival flap during the surgical procedure. ${ }^{(5)}$

MMC is an alkylating antimetabolic, which acts by binding to DNA, resulting in anomalous bonds and breaks in its structure, inhibiting mitosis, protein synthesis and leading to cellular death. ${ }^{(6)}$ It is applied in a preoperative single dose and has been used as an alternative to 5-FU, as it is not necessary multiple subconjunctival injections..$^{(5)}$ In vitro literature demonstrated the 5-FU ability to inhibit fibroblasts. This feature has determined its use in ophthalmology for controlling the recurrence of pterygium and glaucoma surgeries. ${ }^{(7)}$ Antifibroblastic agents have altered the conduct in filtering surgery for glaucoma. Many of them have been used to increase the rate of surgical success, especially in cases that have higher chances of surgical failure. ${ }^{(3)}$ The use of antimetabolic substances associated with trabeculectomy improved IOP control in cases of chronic simple glaucoma and secondary refractory to conventional treatments. ${ }^{(8)}$ However, there are reports of complications with the use of these substances as the formation of large and hyperfiltrant blebs that induce to hypotonia, ocular irritation, and leakage of aqueous humor with Seidel + . Those side effects usually occurs in the early postoperative period and induces to hypotony, shallow anterior chamber and difficulty in forming filtrating bubble ${ }^{(9)}$. Serious complications can occur late in these cases, like endophthalmitis and hypotonic maculopathy that demonstrate the need to increase the safety of these procedures. ${ }^{(10)}$

Cyclophosphamide is a nitrogen mustard group used as cytotoxic or cytostatic drug, also known as antineoplastic. It integrates a subgroup of substances designated as alkylating agents, which is effective against slow growth tumors that damage cells at any phase of cell growth. Alkylating agents have the property of becoming strong electrolytes through the formation of intermediate carbon ions or transition of complexes with target molecules, which may include guanine and other components of DNA. ${ }^{(11)}$

This study has the purpose to evaluate clinically, the effects of subconjunctival cyclophosphamide injection, in the eye of rabbits, as a preliminary study to evaluate this drug as an alternative to MMC and as an antifibroblastic agent in humans.

\section{Methods}

We used in this study 20 albino female rabbits of New Zealand race (Oryctologuscunicullus), aged between 6 and 24 months, weighing between 2 and 6 kilograms, without external injuries and no detectable pathological changes in the eyes of the animals, which were housed in appropriate cages in vivarium with experience in handling of these animals. Before the procedure, the animals were submitted to 12 to 16 hours of fasting, avoiding even the water intake. It was administered $0.2 \mathrm{ml} / \mathrm{kg}$ of $0.2 \%$ acepromazine (Univet, Cambuci, SP/Brazil) intramuscular (IM) as tranquilizer pre-anesthetic medication. Shortly thereafter, it was administered $0.1 \mathrm{ml} / \mathrm{kg}$ of $1 \%$ atropine IM (Calbos Laboratory, Curitiba/Brazil) and Hydrochloride- (2,6-xylidine) -5,6-dihydro-4H-1 ,3-thiazine (Bayer, Sao Paulo, SP/Brazil) 9.0 $\mathrm{mg} / \mathrm{kg}$ of body weight IM as a sedative and muscle relaxant associated with ketamine hydrochloride in 10\% (União Química Farmacêutica Nacional, Embu, SP/Brazil) at a dose of $35.0 \mathrm{mg} /$ $\mathrm{kg} \mathrm{IM}$ as an anesthetic.

Anesthesic action was monitored by means of the presence or absence of eyelid, interdigital reflexes, and ear clamping. Surgical anesthesia was obtained when such reflexes were lost. In addition, physiological parameters, such as, heart rate, respiratory rate, quality of peripheral pulse, capillary filling time, mucosal color and temperature were checked. Ventilation was spontaneous throughout the procedure, followed by oxygen therapy using a veterinary mask and oxygen supplied to $2 \mathrm{l} / \mathrm{min}$, without major complications during the procedure. After the anesthetic procedure, all rabbits underwent a subconjunctival injection in a volume of $0.3 \mathrm{ml}$ of $10 \mathrm{mg} / \mathrm{ml}$ cyclophosphamide in left eye.

The rabbits were evaluated in the slit lamp, searching for presence of iritis, anterior chamber reaction or other inflammatory ocular signs. The evaluations were at 1 th, 7 th, 30 th and 60 th days after the procedure. We searched for the presence of ocular reactions such as: conjunctival necrosis, hyperemia, chemosis, secretion, opacity, iritis.

The occurrence of the reactions to the injection in the eye was analyzed descriptively by absolute and relative frequency (\%) on each assessment day and was built a confidence interval of $95 \%$ (IC95\%) for the single assessment with the presence of an eye with side effects.

The effects found in the sample were analyzed descriptively 
in association and isolated by number of eyes affected.

We used the statistical software SPSS for Windows version 15.0 .

\section{ReSULTS}

The data obtained from each rabbit throughout follow-up of study is in table 1 .

Table 2 shows the incidence of side effects in the sample of 20 rabbits.

\section{DISCUSSION}

Trabeculectomy has been the procedure of choice in patients with glaucoma. The fibroblast proliferation is considered the most common cause of failure of this surgery and therefore the use of antimetabolites in trabeculectomies has been studied for some time. ${ }^{(12)}$

Cyclophosphamide is a potent immunosuppressive drug, acting on cells with high mitotic activity, inhibiting the humoral and cellular responses. ${ }^{(11)}$

In the present study, we evaluated the side effects of $0.3 \mathrm{ml}$ of cyclophosphamide $10 \mathrm{mg} / \mathrm{ml}$ in 20 rabbit eyes. It was observed that from the 20 rabbits $(100 \%)$ studied, three rabbits $(15 \%)$ showed side effects and only at the reading in 24 hours. One rabbit $(5 \%)$ presented only hyperemia, one rabbit (5\%) presented hyperemia associated with iritis and one rabbit (5\%) presented hyperemia associated with secretion. These reactions were not observed at 7 days analysis.

Currently, there is no similar paper in the literature, therefore, we cannot compare the results. In a past study in 2013 , Almodin et al demonstrated the effects of cyclophosphamide on fibroblasts proliferation from primary pterygium in vitro and it

Table 1

Side effects of cyclophosphamide found in the sample

\begin{tabular}{|c|c|c|c|c|c|c|c|}
\hline \multirow[t]{2}{*}{ Animal } & \multicolumn{2}{|c|}{ Weight } & \multirow{2}{*}{$\begin{array}{c}\text { Initial } \\
\text { data reading }\end{array}$} & \multirow{2}{*}{$\begin{array}{l}24 \text { hours } \\
\text { reading }\end{array}$} & \multirow{2}{*}{$\begin{array}{l}7 \text { days } \\
\text { reading }\end{array}$} & \multirow{2}{*}{$\begin{array}{l}30 \text { days } \\
\text { reading }\end{array}$} & \multirow{2}{*}{$\begin{array}{l}60 \text { days } \\
\text { reading }\end{array}$} \\
\hline & Initial & Final & & & & & \\
\hline 1 & 3690 & 3780 & $\mathrm{~W} / \mathrm{A}$ & W/A & $\mathrm{W} / \mathrm{A}$ & $\mathrm{W} / \mathrm{A}$ & $\mathrm{W} / \mathrm{A}$ \\
\hline 2 & 3400 & 3440 & $\mathrm{~W} / \mathrm{A}$ & $\mathrm{W} / \mathrm{A}$ & $\mathrm{W} / \mathrm{A}$ & $\mathrm{W} / \mathrm{A}$ & $\mathrm{W} / \mathrm{A}$ \\
\hline 3 & 3790 & 3840 & $\mathrm{~W} / \mathrm{A}$ & $\mathrm{W} / \mathrm{A}$ & $\mathrm{W} / \mathrm{A}$ & $\mathrm{W} / \mathrm{A}$ & $\mathrm{W} / \mathrm{A}$ \\
\hline 4 & 3740 & 3780 & $\mathrm{~W} / \mathrm{A}$ & $\mathrm{W} / \mathrm{A}$ & $\mathrm{W} / \mathrm{A}$ & $\mathrm{W} / \mathrm{A}$ & $\mathrm{W} / \mathrm{A}$ \\
\hline 5 & 3630 & 3670 & $\mathrm{~W} / \mathrm{A}$ & $\mathrm{W} / \mathrm{A}$ & $\mathrm{W} / \mathrm{A}$ & $\mathrm{W} / \mathrm{A}$ & $\mathrm{W} / \mathrm{A}$ \\
\hline 6 & 3960 & 4090 & $\mathrm{~W} / \mathrm{A}$ & $\mathrm{W} / \mathrm{A}$ & $\mathrm{W} / \mathrm{A}$ & $\mathrm{W} / \mathrm{A}$ & $\mathrm{W} / \mathrm{A}$ \\
\hline 7 & 4020 & 4130 & $\mathrm{~W} / \mathrm{A}$ & $\mathrm{W} / \mathrm{A}$ & $\mathrm{W} / \mathrm{A}$ & $\mathrm{W} / \mathrm{A}$ & $\mathrm{W} / \mathrm{A}$ \\
\hline 8 & 3750 & 3790 & $\mathrm{~W} / \mathrm{A}$ & $\mathrm{W} / \mathrm{A}$ & $\mathrm{W} / \mathrm{A}$ & $\mathrm{W} / \mathrm{A}$ & $\mathrm{W} / \mathrm{A}$ \\
\hline 9 & 3940 & 4020 & $\mathrm{~W} / \mathrm{A}$ & $\mathrm{W} / \mathrm{A}$ & $\mathrm{W} / \mathrm{A}$ & $\mathrm{W} / \mathrm{A}$ & $\mathrm{W} / \mathrm{A}$ \\
\hline 10 & 3920 & 3930 & $\mathrm{~W} / \mathrm{A}$ & $\mathrm{W} / \mathrm{A}$ & W/A & $\mathrm{W} / \mathrm{A}$ & $\mathrm{W} / \mathrm{A}$ \\
\hline 11 & 4000 & 3980 & $\mathrm{~W} / \mathrm{A}$ & $\mathrm{W} / \mathrm{A}$ & $\mathrm{W} / \mathrm{A}$ & $\mathrm{W} / \mathrm{A}$ & $\mathrm{W} / \mathrm{A}$ \\
\hline 12 & 3600 & 3710 & $\mathrm{~W} / \mathrm{A}$ & $\mathrm{W} / \mathrm{A}$ & $\mathrm{W} / \mathrm{A}$ & $\mathrm{W} / \mathrm{A}$ & $\mathrm{W} / \mathrm{A}$ \\
\hline 13 & 3860 & 3970 & $\mathrm{~W} / \mathrm{A}$ & W/A & W/A & $\mathrm{W} / \mathrm{A}$ & $\mathrm{W} / \mathrm{A}$ \\
\hline 14 & 3750 & 3860 & $\mathrm{~W} / \mathrm{A}$ & $\mathrm{W} / \mathrm{A}$ & $\mathrm{W} / \mathrm{A}$ & $\mathrm{W} / \mathrm{A}$ & $\mathrm{W} / \mathrm{A}$ \\
\hline 15 & 3720 & 3600 & $\mathrm{~W} / \mathrm{A}$ & $\mathrm{W} / \mathrm{A}$ & $\mathrm{W} / \mathrm{A}$ & $\mathrm{W} / \mathrm{A}$ & $\mathrm{W} / \mathrm{A}$ \\
\hline 16 & 3470 & 4100 & $\mathrm{~W} / \mathrm{A}$ & Hy, Ir & $\mathrm{W} / \mathrm{A}$ & $\mathrm{W} / \mathrm{A}$ & $\mathrm{W} / \mathrm{A}$ \\
\hline 17 & 3970 & 3580 & $\mathrm{~W} / \mathrm{A}$ & $\mathrm{W} / \mathrm{A}$ & $\mathrm{W} / \mathrm{A}$ & $\mathrm{W} / \mathrm{A}$ & $\mathrm{W} / \mathrm{A}$ \\
\hline 18 & 3570 & 3680 & $\mathrm{~W} / \mathrm{A}$ & $\mathrm{W} / \mathrm{A}$ & W/A & $\mathrm{W} / \mathrm{A}$ & $\mathrm{W} / \mathrm{A}$ \\
\hline 19 & 3940 & 3890 & $\mathrm{~W} / \mathrm{A}$ & $\mathrm{HY}$ & $\mathrm{W} / \mathrm{A}$ & $\mathrm{W} / \mathrm{A}$ & $\mathrm{W} / \mathrm{A}$ \\
\hline 20 & 3630 & 3740 & $\mathrm{~W} / \mathrm{A}$ & $\mathrm{W} / \mathrm{A}$ & $\mathrm{W} / \mathrm{A}$ & W/A & $\mathrm{W} / \mathrm{A}$ \\
\hline
\end{tabular}

Ne: necrosis, Se:secretion, Hy:hyperemia, Op:opacity, Ch:chemosis, Ir:iritis, W/A:without Alteration

Table 2: Incidence of side effects

\begin{tabular}{|c|c|c|c|c|c|}
\hline Variables & Initial reading & $\begin{array}{c}\text { Initial reading } \\
24 \mathrm{hs}\end{array}$ & $\begin{array}{c}\text { Initial reading } \\
7 \text { days } \\
\end{array}$ & $\begin{array}{l}\text { Reading } \\
\text { 30 days }\end{array}$ & $\begin{array}{r}\text { Reading } \\
60 \text { days }\end{array}$ \\
\hline \multicolumn{6}{|l|}{ Side effects, $n(\%)$} \\
\hline Absent & $20(100)$ & $17(85.0)$ & $20(100)$ & $20(100)$ & $20(100)$ \\
\hline IC95\% (\%) & -- & {$[5.2 ; 36.0]$} & --- & -- & -- \\
\hline \multicolumn{6}{|c|}{ Side effects present (associated), n (\%) } \\
\hline Hyperemia & $0(0)$ & $1(5.0)$ & $0(0)$ & $0(0)$ & $0(0)$ \\
\hline \multicolumn{6}{|c|}{ Side effects present (isolated), n (\%) } \\
\hline Hyperemia & $0(0)$ & $3(15.0)$ & $0(0)$ & $0(0)$ & $0(0)$ \\
\hline Iritis & $0(0)$ & $1(5.0)$ & $0(0)$ & $0(0)$ & $0(0)$ \\
\hline Secretion & $0(0)$ & $1(5.0)$ & $0(0)$ & $0(0)$ & $0(0)$ \\
\hline
\end{tabular}


showed significant inhibiton of fibroblasts proliferation with no cell demage until 120 hours of drug exposition. ${ }^{(13)}$

In contrast, several studies have clearly demonstrated that mitomycin $\mathrm{C}$ improves the surgical outcome in patients with high risk of failure; however, some postoperative complications can be linked to its use such as seidel +, ocular hypotony, maculopathy by hypotonia, shallow anterior chamber, epithelial defect, choroidal detachment, cataract and endophthalmitis. ${ }^{(5,13-18)}$

Previous studies shows important histological changes in conjunctiva with mytomicin as inflammatory cells, myofibroblasts and goblet cells. ${ }^{(19,20)}$

Through these and other studies in the literature as Liang et al conducted a study to evaluate the histopathology of a functioning filtrating bleb of a trabeculectomy with mitomycin-c. ${ }^{(21)}$

The purpose of this study was to evaluate by biomicroscopy the effect of the cyclophosphamide subconjunctival injections in rabbit as a preliminary study to verify the safety of this drug, and the possibility to be used in humans. Cyclophosphamide may show less complications than MMC, although we need more studies and surgeries to confirm the action.

\section{Conclusion}

Cyclophosphamide is a drug from the same class that mitomycin $\mathrm{C}$, in our study it showed a safety profile with few side effects when injected subconjunctival in rabbits.

\section{ReFERENCES}

1. Yu DY, Morgan WH, Sun X, Su EN, Cringle SJ, Yu PK, et al. The critical role of the conjunctiva in glaucoma filtration surgery. Prog Retin Eye Res. 2009;28(5):303-28.

2. Mandia JC, Rodrigues ML. Trabeculectomy with mitomycin C in the treatment of refractory glaucoma: evaluating the results of 108 cases. Arq Bras Ophthalmol. 2002;65(5):509-14.

3. Mello e Oliveria N, Port RB, Freitas TG, Lacava AC. Comparative study of the efficacy of trabeculectomy with and without 5-fluorouracil or mitomycin-C. Arq Bras Ophthalmol. 1999;62(6):739-46.

4. Susanna Jr R, Takahashi WY. Comparative study between 5-FU and mitomycin in trabeculectomized eyes. Arq Bras Ophthalmol. 1993; 56(1):25-8.

5. Norris EJ, Schiffman JC, Palmberg FP, Mello PA. Long-term results of the use of antiproliferative drugs in primary trabeculectomy. Arq Bras Ophthalmol. 2002;65(4):1324-30.

6. Cronenberg S, Santos DV, Ramos RF, Oliveira AC, Maestrini HA, Calixto S. Trabeculectomy with mitomycin $\mathrm{C}$ in patients with refractory congenital glaucoma. Arq Bras Ophthalmol. 2004;67(3):475-9.

7. Dorr RT, Soble MJ, Liddil JD, Keller JH. Mitomycin C skin toxicity studies in mice: reduced ulceration and altered pharmacokinetics with topical dimethyl sulfoxide. C J Clin Oncol. 1986; 4(9):1399-404.

8. Gutemberg GC, Silva Filho FJ, Redher JR. Precocious postoperative complications of mitomicina trabeculectomy, in carryng patients with primary open angle glaucoma. Arq Bras Ophthalmol. 2010; 69(2):100-3.
9. Geyer O. Management of large, leaking, and inadvertent filtering blebs with the neodymium:YAG laser. Ophthalmology. 1998;105(6):983-7.

10. Zalta AH, Wieder RH. Closure of leaking filtering blebs with cyanoacrylate tissue adhesive. Br J Ophthalmol. 1991;75(3):170-3.

11. Kanno TY, Sensiate LA, Paula NA, Salles MJ. Toxic effects of the different doses cyclophosphamide on the reproductive parameters of male mice. Braz J Pharm Sci. 2009;45(2):313-19.

12. Giampani J Jr, Borges-Giampani AS, Carani JC, Oltrogge EW, Susanna R Jr. Efficacy and safety of trabeculectomy with mitomycin C for childhood glaucoma: a study of results with long-term follow-up. Clinics (Sao Paulo). 2008;63(4):421-6.

13. Almodin J, Almodin F, Almodin E, Minguetti-Câmara VC, Neves JP, Bezzon AK, et al. Efeitos de algumas drogas sobre a proliferação de fibroblastos de pterígio primário in vitro. Rev Bras Oftalmol. 2013;72(2):108-11.

14. Bindlish R, Condon GP, Schlosser JD, D'Antonio J, Lauer KB, Lehrer $\mathrm{R}$. Efficacy and safety of mitomycin-C in primary trabeculectomy: five-year follow-up. Ophthalmology. 2002;109(7):1336-41.

15. Palanca-Capistrano AM, Hall J, Cantor LB, Morgan L, Hoop J, WuDunn D. Long-term outcomes of intraoperative 5-fluorouracil versus intraoperative mitomycin $\mathrm{C}$ in primary trabeculectomy surgery. Ophthalmology. 2009 Feb;116(2):185-90.

16. Mostafaei A. Augmenting trabeculectomy in glaucoma with subconjunctival mitomycin $\mathrm{C}$ versus subconjunctival 5-fluorouracil: a randomized clinical trial. Clin Ophthalmol. 2011;5:491-4.

17. Pakravan M, Miraftabi A, Yazdani S, Koohestani N, Yaseri M. Topical Mitomycin-C versus subconjunctival 5-Fluoracil for management of bleb failure. J Ophthalmic Vis Res. 2011;6(2):78-86.

18. Mukhopadhyay S, Thakur SK, Dutta J, Prakash R, Shaw C, Gangopadhyay DN, et al. Effect of mitomycin C-aided trabeculectomy on conjunctival goblet cell density. Nepal J Ophthalmol. 2012;4(1):68-72.

19. Yoon SY, Kim ES, Han GS, Suh LH, Jung HS, Tchah H, et al. Correction: safety and efficacy of tacrolimus-coated silicone plates as an alternative to mitomycin $\mathrm{C}$ in a rabbit model of conjunctival fibrosis. PLoS One. 2019;14(12):e0226662.

20. Mietz H, Arnold G, Kirchhof B, Diestelhorst M, Krieglstein GK. Histopathology of episcleral fibrosis after trabeculectomy with and without mitomycin-c. Graefe's Arch Clin Exp Ophtalmol. 1996; 234:364-8.

21. Liang SY, Lee GA, Whitehead K. Histopathology of a functioning mitomycin-C trabeculectomy. Clin Exp Ophthalmol. 2009 Apr;37(3):316-9.

\section{Corresponding author \\ Juliana Almodin}

Rua Silva Jardim, 359

ZIP Code: 87013010

Maringá, PR, Brazil

55-44-998048510 Fax:55-44-32251162

E-mail: juliana_almodin@hotmail.com 